С.О. БУРЧАК

\title{
РОЗВИТОК ТВОРЧОСТІ МАЙБУТНІХ УЧИТЕЛІВ МАТЕМАТИКИ В ЗАРУБІЖНИХ КРАЇНАХ
}

\author{
(C) Бурчак C.O., 2019 \\ http://orcid.org/ 0000-0002-1641-3251 \\ http://doi.org/10.34142/2312-2471.2019.61.03
}

Бажання Украӥни потрапити до Свропейського Союзу вимагає від неї кардинально змінити власну систему освіти, в тому числі й вищу. Тому публікація присвячена аналізу процесу професійної підготовки майбутніх учителів математики зарубіжних країн (Польщуа, Болгарія, Великобританія), зокрема, розвитку творчості майбутніх учителів, оскільки система освіти Украӥни не може в повному обсязі розв'язувати завдання $i$ проблеми, щуо виникають під час організаџї освітнього процесу відомими $i$ звичними способами. Тому $\epsilon$ необхідним врахування навчальних $i$ культурних потреб молоді, можливостей використання в освітньому процесі різноманітних інновацій, а також міжнародного педагогічного досвіду. У зв'язку з ичим, основним завданням статті $\epsilon$ з'ясування стану професійної підготовки майбутніх учителів математики в Польщуі, Болгарії й Великобританії, зокрема з питань розвитку їхньої творчості. У статті представлений аналіз навчальних планів окремих педагогічних закладів вищої освіти окреслених краӥн, компетентностей, набутих випускниками педагогічних університетів. Порівняння прочесу фахової підготовки польських $і$ українських здобувачів показало, щуо найсуттєвішою $\epsilon$ відмінність в годинах, відведених на математичну підготовку майбутніх учителів математики. Крім того, практична підготовка здобувачів частково відрізняється, $і$ майбутні вчителі математики в Польщі, навчаючись у закладах вищої освіти, отримують основи розвитку творчості, оскільки серед знань $i$ компетентностей прослідковусться розвиток окремих особистісних творчих якостей особистості педагога, визначених у межах нашого дослідження. Майбутні вчителі математики в Болгарії та Великобританії, які навчаються у закладах вищиӧ освіти, також отримують основи творчого розвитку, але фрагментарно, не систематично, оскільки серед знань та компетентностей також простежується розвиток окремих особистісних творчих якостей педагога.

Ключові слова: творчість майбутніх педагогів, заклад вищуої освіти, зарубіжні краӥни, здобувачі вищзої освіти, професійна підготовка майбутніх учителів, творчий педагог. 


\section{Burchak S.O. Creativity Development of Future Teachers of Mathematics in Foreign Countries}

Ukraine's desire to join the European Union requires radical changes in its own education system, including higher education. Therefore, the publication is devoted to the analysis of professional training of future teachers of Mathematics in foreign countries (Poland, Bulgaria, Great Britain), in particular, the development of future teachers' creativity, as the education system of Ukraine cannot solve problems fully with known and familiar ways. Therefore, it is necessary to take into account the educational and cultural needs of young people, the possibility of using various innovations in the educational process, as well as international pedagogical experience, so, the main article task is to clarify the training future Mathematics teachers in Poland, Bulgaria and Great Britain in the context of their creativity development. The article presents the analysis of the curriculums of pedagogical universities in higher education in these countries, the competencies acquired by graduates of pedagogical universities. A comparison in the process of professional training Polish and Ukrainian applicants showed that the most significant difference is in the academic hours devoted to mathematical training of future Mathematics teachers. In addition, the practical applicants' training differs in part, and future teachers of Mathematics in Poland, studying in higher education, get the basics of creative development, as among the knowledge and competencies traced the development of certain personal creative teachers' qualities. Future teachers of Mathematics in Bulgaria and Great Britain, studying in higher education, also receive the basics of creative development, but in fragments, not systematically, because among the knowledge and competencies the development of certain personal creative qualities of future teachers is presented.

Key words: creativity of future teachers, universities of higher education, foreign countries, applicants for higher education, professional training future teachers, creative teachers.

Постановка проблеми у загальному вигляді. Бажання України потрапити до Європейського Союзу вимагає від неї кардинально змінити власну систему освіти, в тому числі й вищу. Однією з найвагоміших проблем розвитку сучасної освіти $є$ підготовка майбутніх учителів, і вчителів математики в тому числі. Сучасна школа вимагає підготувати педагогів, у яких сформовані й розвинені здібності, що розкривають індивідуальні якості особистості, інтелектуальні, творчі можливості, а також творчий потенціал [5].

Аналіз останніх досліджень i публікацій. Аналіз психологопедагогічної, філософської літератури показує, що проблема розвитку творчості особистості, у тому числі й майбутнього педагога, висвітлена у вітчизняних та зарубіжних дослідників, а творчість особистості як предмет наукових досліджень зосереджує на собі увагу філософів, психологів, педагогів.

Філософському аспекту вказаного феномену присвячені наукові праці В. Біблера, Ю. Бородай, М. Данилова, К. Кедрова, П. Копщина, О. Коршунова та ін. 
Психологічні основи проблем розвитку творчості знаходимо в наукових працях Д. Богоявленської, Л. Виготського, В. Давидова, Д. Ельконіна, О. Леонтьєва, А. Лука, Я. Пономарьова, С. Рубінштейна та ін.

Педагогічні проблеми розвитку творчості розглядаються в роботах В. Андрєєва, Д. Вількєєва, М. Данилова, Н. Кичук, М. Махмутова, I. Огороднікова, Н. Половнікової, І. Родак, С. Сисоєвої, М. Скаткіна, Т. Шамової, Г. Щукіної та ін.

Виділення невирішених раніше частин загальної проблеми. Система освіти України не може в повному обсязі розв'язувати завдання і проблеми, що виникають під час організації освітнього процесу відомими i звичними способами, у тому числі й проблему розвитку творчості майбутніх освітян, використовуючи лише свій власний досвід. Тому $є$ необхідним врахування навчальних i культурних потреб молоді, можливостей використання в освітньому процесі різноманітних інновацій, а також міжнародного педагогічного досвіду.

Формування цілей статті. Мета - 3'ясувати стан професійної підготовки майбутніх учителів математики в Польщі, Болгарії й Великобританії, зокрема, 3 питань розвитку їхньої творчості.

Виклад основного матеріалу. Проведемо аналіз процесу фахової підготовки майбутніх учителів математики в Польщі. Указана країна географічно виступає нашим найближчим сусідом, який входить до європейського співтовариства. Крім того, нас об'єднує спільна історія, культурне минуле, традиції тощо. Зауважимо, що Польща (як і Україна) має двоступеневу вищу освіту. Але, на відміну від нашої держави, перший ступінь вищої освіти в Польщі триває три роки (180 кредитів ECTS). Зміст фахової підготовки польських педагогів, у тому числі й майбутніх учителів математики, регламентується модернізованим освітнім стандартом [3].

У даному стандарті підготовки здобувачів-математиків передбачається модульне навчання, яке реалізується шляхом опрацювання таких модулів: математична підготовка; психолого-педагогічна підготовка (здійснюється за різними освітніми етапами: 1) дитячий освітній заклад і початкова школа, 2) середня школа, 3) гімназія, 4) післягімназійна школа і професійне навчання, набуття навичок роботи 3 дітьми, що мають особливі потреби; предметнометодична підготовка з математики.

Крім цього, є два факультативних модулі, під час опрацювання яких здобувачі можуть обирати додаткові дисципліни до вивчення другого предмета (четвертий модуль) та підготовку в області спецпедагогіки (п’ятий модуль) [6].

Для аналізу процесу фахової підготовки майбутніх учителів математики в Польщі нами обрано такі заклади вищої освіти: педагогічний університет ім. Комісії національної освіти в Кракові, Поморська академія в Слупську [1].

Під час аналізу нами виявлено, що підготовка майбутніх учителів у Польщі має певні особливості. Так, у закладах вищої освіти Польщі відсутні дисципліни національного напряму, а також екологічні дисципліни. Також виявлено ряд дисциплін, на які у польських закладах відведено значно менше 
часу, ніж в українських: «Етика», «Історія математики» тощо, а серед варіативних дисциплін польських 3ВО взагалі відсутні політологія, релігієзнавство правознавство та ін.

Таким чином, щодо кількості годин, відведених на загальну підготовку майбутніх учителів математики, у польських університетах відведено і меншу кількість годин, і меншу кількість дисциплін, ніж в українських.

Педагогічна практика є передбаченою в університетах Польщі (кількість годин становить 5-7\% від загального навчального навантаження здобувачів), а методичні дисципліни становлять біля 6\% від загальної кількості годин. Педагогічна практика може бути двох видів: загально педагогічна і предметнометодична. Особливості другого виду практики в тому, що вже на першому ступені навчання здобувачі проходять практику з додаткової спеціальності.

Зауважимо, що у всіх університетах країн СC, і у Польщі зокрема, велика увага приділяється навчанню використання інформаційно-комунікаційних технологій у власній професійній діяльності майбутніх педагогів усіх напрямів підготовки, у тому числі й майбутніх учителів математики. У зв’язку з цим, у польських закладах вищої освіти виділено велику кількість годин на лабораторні роботи. Значна увага у польських закладах вищої освіти приділяється вивченню іноземної мови та навчанню інформатики майбутніх учителів математики.

Отже, порівняння процесу фахової підготовки польських і українських здобувачів показало, що найсуттєвішою є відмінність в годинах, відведених на математичну підготовку майбутніх учителів математики. Крім того, частково відрізняється і практична підготовка здобувачів.

Зупинимося детальніше на можливості розвитку творчості майбутніх учителів математики в польських педагогічних закладах вищої освіти. Аналіз освітньої програми підготовки майбутніх учителів математики в педагогічному університеті імені Комісії національної освіти в Кракові показує (авторський переклад), що в переліку знань, які необхідно отримати випускнику університету, поруч із загальними знаннями математики, методики навчання математики, педагогічних, психологічних та інших знань, наявні: розуміння ролі і значення математики та уміння використання в суспільно важливих проектах; розуміння структури математичних теорій, знання математичних засобів, необхідних для опису та аналізу математичних моделей в інших галузях науки; знання основ числення та інтегралу однієї і багатьох змінних, прикладів використання його під час розв'язування прикладних задач, вибраних понять лінійної алгебри та топології; знання основних потреб i проблем сучасності цивілізації, під час розв’язання яких може бути корисна математика.

Крім того, розглянувши соціальні компетентності, розвиток яких $є$ необхідним під час навчання в педагогічному університеті здобувачеві, відмітимо наступні: усвідомлення повноти власних знань і умінь, розуміння необхідності їх доповнення, зокрема потреба в самонавчанні й самовихованні; можливість сформулювати питання, поглиблення власного розуміння певної 
теми, вміння знайти відсутні елементи в логіці міркування; вміння працювати в команді, розуміння необхідності систематичної роботи над творчими проектами, що мають довгостроковий характер; розуміння і цінування чесності й добропорядності у власній інтелектуальній діяльності, а також етичного використання інтелектуальних здобутків інших людей; можливість самостійного пошуку інформації в літературі, у тому числі й іноземними мовами; можливість сформулювати думки щодо розв’язування математичних задач, у тому числі й нестандартних.

Як бачимо, майбутні учителі математики Польщі, навчаючись у закладах вищої освіти, отримують основи розвитку творчості, оскільки серед знань i компетентностей прослідковується розвиток окремих особистісних творчих якостей особистості педагога, визначених у рамках нашого дослідження.

Розглянемо особливості фахової підготовки майбутніх учителів математики в Болгарії. Для аналізу ми відібрали навчальний план і освітню програму підготовки бакалавра у Шуменському університеті імені Спископа Костянтина Преславського [8].

Навчальний план підготовки бакалаврів в указаному педагогічному університеті представлено в табл. 1.

Таблиия 1

НАВЧАЛЬНИЙ ПЛАН (ШУМЕНСЬКИЙ УНІВЕРСИТЕТ ІМЕНІ ЕПИСКОПА КОСТЯНТИНА ПРЕСЛАВСЬКОГО)

\begin{tabular}{|c|c|c|}
\hline $\begin{array}{c}\text { № } \\
\Pi / \Pi\end{array}$ & Назва навчальної дисципліни & $\begin{array}{c}\text { Кількість кредитів } \\
\text { ЕСТS (к-сть } \\
\text { годин) }\end{array}$ \\
\hline \multicolumn{3}{|c|}{ І рік навчання } \\
\hline \multicolumn{3}{|c|}{ Семестр 1} \\
\hline 1. & Лінійна алгебра & $8(240)$ \\
\hline 2. & Математичний аналіз (I частина) & $9(270)$ \\
\hline 3. & Практикум з інформаційних технологій & $4(120)$ \\
\hline 4. & Психологія & $4(120)$ \\
\hline 5. & Факультативна дисципліна I (Математика & $5(150)$ \\
\hline \multicolumn{3}{|c|}{ Семестр 2} \\
\hline 6. & Аналітична геометрія & $6(180)$ \\
\hline 7. & Математичний аналіз (II частина) & $8(240)$ \\
\hline 8. & Програмування (I частина) & $8(240)$ \\
\hline 9. & Іноземна мова (Англійська мова) & $2(60)$ \\
\hline 10. & Педагогіка & $4(120)$ \\
\hline 11. & Факультативна дисципліна II (Математика) & $2(60)$ \\
\hline \multicolumn{3}{|c|}{ ІІ рік навчання } \\
\hline \multicolumn{3}{|c|}{ Семестр 3} \\
\hline 12. & Математичний аналіз (III частина) & $7(210)$ \\
\hline 13. & Програмування (II частина) & $6(180)$ \\
\hline
\end{tabular}




\begin{tabular}{|c|c|c|}
\hline 14. & Алгебра( I частина) & $7(210)$ \\
\hline 15. & Геометрія ( I частина) & $5(150)$ \\
\hline 16. & Факультативна дисципліна III & $3(90)$ \\
\hline 17. & Факультативна дисципліна IV: Спорт & $2(60)$ \\
\hline \multicolumn{3}{|c|}{ Семестр 4} \\
\hline 18. & Математичний аналіз (IV частина) & $6(180)$ \\
\hline 19. & Алгебра (II частина) & $6(180)$ \\
\hline 20. & Шкільний курс алгебри & $8(240)$ \\
\hline 21. & Комп’ютерні системи & $5(150)$ \\
\hline 22. & Вибіркова дисципліна I (Математика) & $5(150)$ \\
\hline \multicolumn{3}{|c|}{ ІІІ рік навчання } \\
\hline \multicolumn{3}{|c|}{ Семестр 5} \\
\hline 23. & Диференціальні рівняння & $6(180)$ \\
\hline 24. & Числові методи & $5(150)$ \\
\hline 25. & Теорія чисел & $4(120)$ \\
\hline 26. & Шкільний курс геометрії & $7(210)$ \\
\hline 27. & Загальна методика навчання математики & $6(180)$ \\
\hline 28. & $\begin{array}{l}\text { Вибіркова дисципліна } \\
\text { інформатики) }\end{array}$ & $2(60)$ \\
\hline \multicolumn{3}{|c|}{ Семестр 6} \\
\hline 29. & Методика навчання математики (вибрані питання) & $4(120)$ \\
\hline 30. & Практикум з web-технологій & $2(60)$ \\
\hline 31. & Комплексний аналіз & $6(180)$ \\
\hline 32. & Теорія ймовірностей та математична статистика & $6(180)$ \\
\hline 33. & 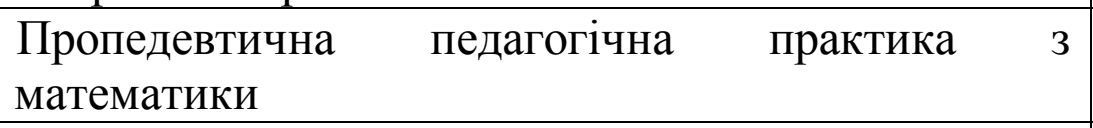 & $2(60)$ \\
\hline 34. & $\begin{array}{l}\text { Пропедевтична } \\
\text { інформатики }\end{array}$ & $2(60)$ \\
\hline 35. & $\begin{array}{l}\text { Шкільний курс інформатики } 3 \text { методикою } \\
\text { викладання інформатики }\end{array}$ & $5(150)$ \\
\hline 36. & Вибіркова дисципліна III (Методика) & $3(90)$ \\
\hline \multicolumn{3}{|c|}{ IV рік навчання } \\
\hline \multicolumn{3}{|c|}{ Семестр 7} \\
\hline 37. & Поточна педагогічна практика з математики & $4(120)$ \\
\hline 38. & Поточна педагогічна практика з інформатики & $3(90)$ \\
\hline 39. & Геометрія II част (Диференціальна) & $8(240)$ \\
\hline 40. & Математичний практикум & $4(120)$ \\
\hline 41. & $\begin{array}{l}\text { Шкільний курс інформатики з методикою } \\
\text { викладання інформатики }\end{array}$ & $7(210)$ \\
\hline 42. & Вибіркова дисципліна IV (Математика) & $4(120)$ \\
\hline \multicolumn{3}{|c|}{ Семестр 8} \\
\hline 43. & $\begin{array}{l}\text { Переддипломна педагогічна практика } 3 \\
\text { математики }\end{array}$ & $5(150)$ \\
\hline
\end{tabular}


Збірник наукових праць «Педагогіка та психологія». - Харків, 2019. - Вип. 61.

\begin{tabular}{|c|l|c|}
\hline $\mathbf{4 4 .}$ & $\begin{array}{l}\text { Переддипломна педагогічна практика 3 } \\
\text { інформатики }\end{array}$ & $3(90)$ \\
\hline $\mathbf{4 5 .}$ & Вибіркова дисципліна V (Методика) & $3(90)$ \\
\hline $\mathbf{4 6 .}$ & Вибіркова дисципліна VI (Інформатика) & $2(120)$ \\
\hline $\mathbf{4 7 .}$ & $\begin{array}{l}\text { Вибіркова дисципліна VII (Практикум 3 } \\
\text { інформатики) }\end{array}$ & $3(60)$ \\
\hline $\mathbf{4 8 .}$ & $\begin{array}{l}\text { Вибіркова дисципліна VIII (Практикум 3 } \\
\text { інформатики) }\end{array}$ \\
\hline
\end{tabular}

Отже, розподіл навчального навантаження: математичні дисципліни $47 \%$; дисципліни методичного спрямування - 20\%; комп'ютерні дисципліни $23 \%$; психолого-педагогічні дисципліни - 3\%; мовна підготовка (вивчення іноземної мови) - $2 \%$.

Розглянемо більш детально можливості розвитку творчості майбутніх учителів математики в болгарському педагогічному університеті, що $\epsilon$ особливо цікавим у рамках нашого дослідження.

Аналіз кваліфікаційної характеристики спеціальності «Педагогіка. Математика i інформатика», області вищої освіти «Педагогічні науки», професійної спрямованості «Педагогіка. Математика і інформатика», освітньокваліфікаційного ступеня «Бакалавр», професійної кваліфікації «Учитель математики, інформатики й інформаційних технологій» показав, що поруч із загальними знаннями й компетентностями, необхідними вчителю математики, присутні й такі: проведення аналізу і синтезу, порівняння, класифікації i систематизації математичних понять і фактів, уміння будувати причиннонаслідкові зв'язки, загального і одиничного; підбирання оптимальних способів розв'язування завдань (математичних і нематематичних), сприяння розвитку інноваційного мислення; використання на практиці новітніх інформаційних технологій; організація співпраці із закладами освіти та іншими організаціями як у своїй країні, так і в країнах Свропейського Союзу.

Oсобистісні компетентності: опанування теоретичних знань 3 арифметики, алгебри, геометрії, математичного аналізу, інформатики й інформаційних технологій; пізнання теорій, концепцій, принципів i закономірностей психологічного розвитку учнів.

Професійні компетентності: уміння інтеграції знань i вмінь у професійно-практичній дійсності; уміння створювати проекти освітньої спрямованості для вітчизняних і зарубіжних організацій; уміння опрацьовувати спеціалізовану літературу й інформацію; уміння на високому рівні самостійності пропонувати сучасні підходи і методи розв’язання різноманітних завдань.

Технологічні компетентності: уміння використовувати сучасні освітні технології у навчанні математики, інформатики, сучасних інформаційних технологій; уміння застосовувати отримані знання й уміння в нових умовах; спосібність до формування власної думки під час розв'язання певної проблеми з питань навчання математики, інформатики, інформаційних технологій. 
Таким чином, майбутні учителі математики Болгарії, навчаючись у закладах вищої освіти, також отримують основи розвитку творчості, оскільки серед знань i компетентностей прослідковується розвиток окремих особистісних творчих (креативних) якостей особистості майбутнього педагога.

В останні часи у Великобританії прослідковуються новітні підходи до фахової підготовки педагогічних працівників, у тому числі й учителів математики, основним 3 яких прийнято вважати практико-орієнтований [Новикова Ю.Б. Практико-ориентированный подход к профессиональной]. У зв'язку з цим, підвищеної зацікавленості викликає процес вивчення теоретикометодологічних засад підготовки майбутнього вчителя, зокрема і вчителя математики у вказаній країні.

Як стверджує знавець системи освіти Великобританії Ю. Новікова, галузь знань «Освіта» представлена у британських закладах вищої освіти трьома основними групами освітніх програм: педагогічні науки («Education», «Education Studies»); дошкільна освіта («Early Years Studies», «Childhood Studies»); початкова і середня освіта («Primary Education», «Secondary Education»).

Програми першої групи характеризуються вивченням фундаментальних дисциплін (педагогіки, психології, історії й філософії освіти) та великим об'ємом науково-дослідної роботи здобувачів теоретичного характеру. Випускники таких програм отримують степінь бакалавра гуманітарних або природничих наук, але не $\epsilon$ вчителями. Вони можуть вступати на післядипломні педагогічні програми освітніх організацій університетського i неуніверситетського типів [7].

Розглянемо програми групи «Початкова i середня освіта («Primary Education», «Secondary Education»), оскільки вони є першим ступенем фахової підготовки майбутніх учителів у початковій i середній школах, а тому викликають інтерес у рамках нашого дослідження. Для порівняння і аналізу ми відібрали програми підготовки вчителів у британських закладах Едж Хілл (Edge Hill University) [2] та Сандерленд (Sunderland University)[4].

Аналіз указаних програм показав, що вони розраховані на різну кількість кредитів: в університеті Едж Хілл на навчальні дисципліни відведено 360 академічних кредитів, а на педагогічну практику - 80 кредитів; у Сатерленд (Sunderland University) на всі навчальні дисципліни разом 3 педагогічною практикою відведено 360 академічних кредитів.

Не зважаючи не деяку розбіжність у кількості академічних кредитів, в обох закладах освіти присутні багато спільних моментів: фахова підготовка здобувачів освіти розрахована на три роки, дисципліни загальної підготовки майже не вивчаються, велику увагу приділено педагогічним практикам.

Разом 3 тим, педагогічна практика організована в різних університетах по-різному: у Едж Хілл на першому році навчання здобувачі проходять професійну практику 1А (20 кредитів), на другому - професійну практику 1Б (20 кредитів), на третьому - професійну практику 2 (40 кредитів). Разом - 80 кредитів (18\% загальної кількості кредитів навчального плану); у Сатерленд 
(Sunderland University) практика триває протягом всього третього року навчання (The Professional Year), оскільки вона містить i написання індивідуальної роботи. Виділено на неї 120 кредитів (33\% загальної кількості кредитів навчального плану).

Н. Кугай, аналізуючи систему освіти Великобританії стверджує, що у програмі підготовки майбутнього вчителя математики в університеті Едж Хілл велику увагу приділено математичній підготовці здобувачів: 200 британських кредитів (46\%) [6].

Згідно з програмою, вивчаються математичні дисципліни: «Математичне доведення і логіка», «Неперервні функції», «Алгебраїчні та геометричні структури», «Лінійна алгебра», «Теорія чисел», «Математична статистика», «Дискретна математика», «Математичні моделі», «Звичайні диференціальні рівняння» (20 академічних кредитів на дисципліну). Педагогічні дисципліни 80 кредитів (18\%). Решта - методичні дисципліни, на які відведено 80 кредитів $(18 \%)$.

У програмі університету Сандерленд (Sunderland University) на математичні дисципліни відведено 160 кредитів (45\%). Значної уваги тут приділено методу моделювання в математиці та практичному застосуванню математики («Моделі в математиці» (20 кредитів), «Структура і модель» (20 кредитів), «Практичні застосування математики» (20 кредитів)). Психологопедагогічним дисциплінам відведено 40 кредитів (11\%), методичним - 40 кредитів (11\%) [6].

Отже, нормативні документи процесу фахової підготовки майбутніх учителів математики у закладах освіти Великобританії дещо відрізняються від відповідних нормативів нашої країни, Польщі, Болгарії. Основна відмінність кількість кредитів, відведених на педагогічні практики. Математичні дисципліни в університетах окреслених країн займають практично однаковий відсоток від усього навчального навантаження майбутніх учителів математики.

Розглянемо детальніше зміст дисциплін освітньої програми університетів Великобританії (на прикладі програми закладу Едж Хілл (Edge Hill University) [2) 3 метою аналізу можливостей розвитку творчості майбутніх учителів математики у Великобританії, що є цікавим у рамках нашого дослідження.

Дисципліна «Особиста та професійна поведінка - перехід до вищої освіти та викладацької професії (20 кредитів)» вивчається на першому році навчання. Основні завдання даного модуля є набуття необхідних навичок академічного навчання та необхідних професійних навичок педагогічного досвіду. Модуль також має підвищити професійну обізнаність про важливість викладання дисциплін у середній школі. Мета: заохотити здобувачів до розуміння зв'язків між теоретичними знаннями та впровадженням національної політики та ініціатив, з практичним досвідом. Самооцінка, рефлексія та встановлення цілей професійного розвитку є ключовими особливостями модуля.

Дисципліна «Принципи, педагогіка та планування 3 математики (20 кредитів)» вивчає спеціальні професійні обов'язки, що стосуються майбутніх учителів математики. Модуль дає змогу розвивати необхідні професійні 
навички та знання метою здобуття власного педагогічного досвіду. Сюди входить навчання планувати та проводити ефективні та добре структуровані уроки, які сприятимуть любові до навчання та заохочуватимуть дітей до пізнання i розвитку інтелектуальних здібностей. Крім того, модуль вчить планувати й ефективно використовувати домашні завдання, позакласні заходи для закріплення та розширення знань учнів.

Крім указаних модулів, на першому році фахової підготовки майбутніх учителів математики вивчаються: «Професійна практика 1А (20 кредитів)», «Математичні доведення та логіка (20 кредитів», «Математичне моделювання (20 кредитів)», «Неперервні функції (20 кредитів)», «Дослідження алгебраїчних та геометричних структур (20 кредитів)», які в тій чи іншій мірі допускають розвиток окремих особистих креативних якостей особистості, але не системно i досить фрагментарно.

Аналізуючи зміст дисциплін, що згідно програми вивчаються на другому році професійної підготовки майбутніх учителів математики, виділимо дисципліну «Особиста та професійна поведінка - юридичні вимоги до професійної практики (20 кредитів)». Цей модуль допомагає зрозуміти необхідну професійну поведінку, обов'язки та відповідальність вчителя середньої школи. Самооцінка, рефлексія та встановлення цілей професійного розвитку є ключовими особливостями вказаного модуля.

Модуль «Творче планування та викладання математики в школі (20 кредитів)» дозволяє розглянути ефективне викладання математики шляхом обговорення та оцінки альтернативних підходів. Крім того, модуль визначає роль математики у навчальній програмі та встановлює між предметні зв'язки 3 рядом інших шкільних предметів. Модуль концентрується на процесах планування, викладання та оцінювання навчальних досягнень школярів, що й складають фундамент ефективної професійної практики, яка визначає основу постійного професійного розвитку.

Дисципліна «Навчальні методи дослідження для вдосконалення школи (20 кредитів)» ознайомлює 3 якісними та кількісними методами навчальних досліджень, що сприяють самовдосконаленню вчителя й учня. Ключовим елементом модуля $\epsilon$ розгляд, опрацювання i розуміння публікацій, розмірковуючи над методичними питаннями. Модуль продемонструє ознайомлює 3 дослідженнями як у педагогіці, так і у вибраній предметній області та заохотить здобувачів вищої освіти критично оцінити власне навчання.

Разом з указаними модулями, на другому році підготовки ще вивчаються «Професійна практика 1B (20 кредитів)», «Статистика (20 кредитів)», «Дискретна математика (20 кредитів)», «Лінійна алгебра (20 кредитів)».

Зауважимо, що на другому році навчання серед указаних модулів, під час вивчення яких можливий не системний розвиток творчості майбутніх учителів, присутній модуль «Творче планування та викладання математики в школі», який цілеспрямовано розвиває власні творчі якості майбутніх учителів математики. 
Серед дисциплін, що вивчаються згідно освітньої програми на третьому році підготовки майбутніх учителів математики виділяємо «Особиста та професійна поведінка - працездатність (20 кредитів)», який розвиває професійні навички академічного навчання необхідні для вищої освіти та для професійної практики. Крім того, модуль дає змогу розширити професійні знання щодо стандартів поведінки вчителів, підвищити працездатність, підготуватися до заявок на роботу та співбесіди тощо. Самооцінка, рефлексія та встановлення цілей професійного розвитку є ключовими особливостями модуля.

Дисципліна «Математичні моделі (20 кредитів)» охоплює знання диференціальних рівнянь та присвячена розв'язанню прикладних задач. Моделювання ілюструє, як можна використовувати математику в широкому діапазоні ситуацій, наприклад, для розв'язання проблем фізики, хімії, механіки та інших наук.

Разом 3 іншими модулями, що вивчаються на третьому році підготовки, указані дисципліни досить поверхнево, не систематично сприяють розвитку творчості майбутніх учителів математики.

Висновки. Аналіз процесу фахової підготовки майбутніх учителів математики в Україні, Болгарії, Польщі, Великобританії показав, що у всіх перелічених країнах фрагментарно, не систематично відбувається розвиток творчості майбутніх педагогів. Разом з тим, освітня програма Великобританії передбачає модуль «Творче планування та викладання математики в школі», який цілеспрямовано розвиває окремі творчі якості майбутніх учителів математики, але все ж теоретичні і методичні засади розвитку творчості майбутніх учителів математики в повній мірі в сучасних програмах все ще не висвітлюється.

Перспективи вбачаємо в аналізі фахової підготовки майбутніх учителів математики інших країн.

\section{Jimepamypa}

1. Akademia Pomorska w Słupsku, Instytut Matematyki. [Elektronnyy resurs]. Rezhym dostupu: http://matematyka.apsl.edu.pl/dydaktyka/plany-zajec.

2. Edge Hill University. [Elektronnyy resurs]. - Rezhym dostupu: https://www.edgehill.ac.uk/courses/secondary-mathematicseducationwithqts/tab/modules

3. Rozporządzenie Ministra Nauki i Szkolnictwa Wyŝszego z dnia 17 stycznia 2012 r. w sprawie standardow kształcenia przygotowującego do wykonywania zawodu nauczyciela. Rezhym dostupu: http://isap.sejm.gov.pl/Download?id=WDU20120000131\&type $=2$

4. Sunderland university. [Elektronnyy resurs]. Rezhym dostupu: http://www.sunderland.ac.uk/courses/educationandsociety/und ergraduate/mathematics-education-11-18-qts/\#tab_content

5. Бурчак С. Підготовка майбутніх учителів початкових класів до розвитку творчого мислення учнів у процесі навчання математики: метод. пос. Суми: РВВ СОІППО, 2010. 116 с. 
6. Кугай Н.В. Методологічні знання майбутнього вчителя математики: монографія. Харків: ФОП Панов А.М., 2017. 336 с.

7. Новикова Ю.Б. Практико-ориентированный подход к профессиональной подготовке британского учителя (конец XX - начало XXI вв.): дис. канд. пед. наук: 13.00.01. М., 2014. 208 с.

8. Шуменски университет «Епископ Константин Преславски», Факултет по математика и информатика. URL : http://shu.bg/razpisi-igrafici? speciality $=155$

\section{References}

1. Akademia Pomorska w Słupsku, Instytut Matematyki. [Elektronnyy resurs]. Rezhym dostupu: http://matematyka.apsl.edu.pl/dydaktyka/plany-zajec.

2. Edge Hill University. [Elektronnyy resurs]. - Rezhym dostupu: https://www.edgehill.ac.uk/courses/secondary-mathematicseducation- $\quad$ withqts/tab/modules

3. Rozporządzenie Ministra Nauki i Szkolnictwa Wyŝszego z dnia 17 stycznia 2012 r. w sprawie standardow kształcenia przygotowującego do wykonywania zawodu nauczyciela. Rezhym dostupu: http://isap.sejm.gov.pl/Download?id=WDU20120000131\&type $=2$

4. Sunderland university. [Elektronnyy resurs]. Rezhym dostupu: http://www.sunderland.ac.uk/courses/educationandsociety/und ergraduate/mathematics-education-11-18-qts/\#tab_content

5. Burchak S. (2010) Pidgotovka majbutnih uchiteliv pochatkovih klasiv do rozvitku tvorchogo mislennya uchniv u procesi navchannya matematiki. [Preparing future primary school teachers to develop students' creative thinking in mathematics learning]. Sumi: SOIPPO. 116 p. (in Ukrainian).

6. Kugaj N.V. (2017) Metodologichni znannya majbutn`ogo vchy`telya matematy ky: monografiya. [Methodological knowledge of the future teacher of mathematics: monograph]. Xarkiv: FOP Panov A.M., 2017. 336 p. (in Ukrainian).

7. Novy`kova Yu.B. (2014) Prakty`ko-ory`enty'rovanniy podxod $k$ professy`onal'noj podgotovke bry`tanskogo uchy'telya (konecz XX - nachalo XXI $v v$.): [Practice-oriented approach to British teacher training (late twentieth - early twenty-first century)] : dy`s. kand. ped. nauk: 13.00.01. M., 2014. 208 p. (in Russia).

8. Shumensky uny versy tet «Epy skop Konstanty`n Preslavsky », Fakultet po matematy $k a y^{\prime} y^{\prime n}{ }^{\prime}$ ormaty $^{\prime} k a$. [University of Shumen "Bishop Konstantin Preslavski", Faculty of Mathematics and Informatics]. URL http://shu.bg/razpisi-igrafici? speciality $=155$ (in Bulgaria). 